\title{
Antiperinuclear factor in juvenile rheumatoid arthritis
}

\author{
Gideon Nesher, Terry L Moore, Michael W Grisanti, Eva El-Najdawi, Thomas G Osborn
}

Division of

Rheumatology,

St Louis University

School of Medicine,

St Louis, MO, USA

G Nesher

T L Moore

M W Grisant

E El-Najdawi

T G Osborn

Hebrew UniversityHadassah Medical

School, Shaare Zedek

Medical Center,

Jerusalem, Israel

G Nesher

Cardinal Glennon

Children's Hospital,

St Louis, MO, USA

T L Moore

Correspondence to:

Dr Terry L Moore,

Division of Rheumatology,

St Louis University

School of Medicine

1402 South Grand Boulevard,

R215 Doisy Hall, St Louis,

MO 63104, USA.

Accepted for publication

14 May 1991

\begin{abstract}
The serological diagnosis of juvenile rheumatoid arthritis (JRA) is difficult, with only $7-10 \%$ of patients $19 \mathrm{~S}$ IgM rheumatoid factor positive. About $60-70 \%$ of patients are positive for hidden 19S IgM rheumatoid factor, but this test requires serum separation and is not available in most laboratories. Antiperinuclear factor has been described in both seropositive and seronegative adult patients with rheumatoid arthritis, but has not been thoroughly evaluated in children with JRA. This study determined the diagnostic sensitivity and specificity of antiperinuclear factor in patients with JRA.
\end{abstract}

Serum samples from 64 children with JRA, 24 with systemic lupus erythematosus (SLE), and 24 control subjects were tested for the presence of antiperinuclear factor. A total of $10(83 \%)$ of seropositive, polyarticular onset and six $(37 \%)$ of seronegative, polyarticular onset patients with JRA were positive for antiperinuclear factor. The occurrence of antiperinuclear factor in five $(19 \%)$ with pauciarticular onset and one $(10 \%)$ with systemic onset (JRA) as well as in four (17\%) with SLE was not increased compared with the control subjects $(1 / 24(4 \%))$.

These data show an overall diagnostic sensitivity and specificity of 34 and $90 \%$ respectively in this group of patients. Although less sensitive than the hidden rheumatoid factor assay, the antiperinuclear factor assay is easier to perform and may contribute to the serological diagnosis of JRA.

Antiperinuclear factor is an antibody (or antibodies) that binds to $0 \cdot 2-3 \cdot 0 \mu \mathrm{m}$ keratohyaline granules surrounding nuclei of human buccal mucosal cells. ${ }^{12}$ The biochemical nature of the antigen is unknown. It stains positively with methylene blue and periodic acid-Schiff and does not contain DNA or RNA. ${ }^{3}$ Antiperinuclear factor has been found in $48-92 \%$ of patients with rheumatoid arthritis (RA), mostly in patients seropositive for $19 \mathrm{~S}$ IgM rheumatoid factor, but also in $10-76 \%$ of seronegative patients. ${ }^{12}$ 4-11 Its occurrence in healthy adult controls and patients with other connective tissue diseases is in the range $0-14 \%^{1}{ }^{2} 4-810{ }^{11}$; however, one study reported a higher frequency in patients with systemic lupus erythematosus (SLE) and scleroderma (46 and $26 \%$ respectively). ${ }^{9}$ The presence of antiperinuclear factor correlates with disease severity ${ }^{25}$ and also with the presence of rheumatoid factor ${ }^{124-7}$ and HLA-DR4. ${ }^{12}$ Data for antiperinuclear factor in children have only been reported by Janssens $e t ~ a l,{ }^{7}$ who found three positive antiperinuclear factor reactions in 13 patients with juvenile rheumatoid arthritis (JRA).

In the present study, we determined the occurrence of antiperinuclear factor in four different onset types of JRA, in children with SLE, and in healthy control children to establish whether the antiperinuclear factor assay can aid in the diagnosis of JRA.

\section{Materials and methods}

PATIENTS AND CONTROLS

Serum samples were collected from 112 children: 26 had pauciarticular onset JRA, 12 had seropositive and 16 had seronegative polyarticular onset JRA, 10 had systemic onset JRA, and 24 had SLE. The control subjects were 24 children with non-inflammatory musculoskeletal symptoms. Patients with JRA and SLE met the respective criteria of the American College of Rheumatology. ${ }^{1314}$ All patients were followed up at the St Louis University Rheumatology Clinic, at the Cardinal Glennon Children's Hospital, or the St. Louis University Doctors' Office Building. The study was approved by the St. Louis University Institutional Review Board.

\section{ANTIPERINUCLEAR FACTOR ASSAY}

This was determined as previously described by Nienhuis and Mandema. ${ }^{1}$ Briefly, human buccal mucosal cells were obtained by scraping the inner side of the cheeks of healthy donors with a wooden tongue depressor, followed by rinsing in $0.15 \mathrm{~mol} / \mathrm{l}$ phosphate buffered saline (pH 7.2). Cells were washed three times in phosphate buffered saline, spun onto a microscope slide using a cytospin centrifuge, and fixed with acetone. After drying, the cell preparations were incubated for $\mathbf{9 0}$ minutes at room temperature with undiluted serum samples and serum samples diluted 1:5, 1:10, and 1:20. Fractions of selected serum samples were used when positive for antiperinuclear factor. Slides were washed three times with phosphate buffered saline, dried, and incubated with fluorescent antihuman gammaglobulins (Antibodies, Davis, CA, USA) for 30 minutes. The slides were then washed three times in phosphate buffered saline, air dried, mounted with glycerol, and studied with a fluorescence microscope (Laborlux II, Leitz). The fluorescence of perinuclear homogeneous spheres was considered to be a positive test for antiperinuclear factor. 
Presence of antiperinuclear factor in children with juvenile rheumatoid arthritis, systemic lupus erythematosus, and control subjects. Results given are number positive (\%).

\begin{tabular}{|c|c|c|c|c|}
\hline \multirow[t]{2}{*}{ Disease } & \multicolumn{4}{|c|}{ Positive APF (\%) } \\
\hline & $\begin{array}{l}\text { Undilued } \\
\text { serum }\end{array}$ & $\begin{array}{l}1: 5 \\
\text { dilution }\end{array}$ & $\begin{array}{l}1: 10 \\
\text { dilution }\end{array}$ & $\begin{array}{l}1: 20 \\
\text { dilution }\end{array}$ \\
\hline $\begin{array}{l}\text { Fuvenile rheumatoid arthritis } \\
\text { Polyarticular onset, seropositive }(n=12) \\
\text { Polyarticular onset, seronegative }(n=16) \\
\text { Pauciarticular onset }(n=26) \\
\text { Systemic onset }(n=10) \\
\text { Total }(n=64) \\
\text { Systemic lupus erythematosus }(n=24) \\
\text { Control subjects }(n=24)\end{array}$ & $\begin{array}{l}10(83)^{*} \\
6(37)^{* *} \\
5(19) \\
1(10) \\
22(34)^{* *} \\
4(17) \\
1(4)\end{array}$ & $\begin{array}{l}9(75)^{*} \\
5(31)^{* *} \\
5(19) \\
1(10) \\
20(31)^{* *} \\
2(8) \\
0\end{array}$ & $\begin{array}{l}3(25) \\
2(12) \\
1(4) \\
1(10) \\
7(11) \\
1(4) \\
0\end{array}$ & $\begin{array}{l}1(8) \\
2(12) \\
1(4) \\
1(10) \\
5(8) \\
0 \\
0\end{array}$ \\
\hline
\end{tabular}

$\mathrm{APF}=$ antiperinuclear factor.

${ }^{*} \mathrm{p}<0.001 v$ controls; ${ }^{* *} \mathrm{p}<0.05 v$ controls.

STATISTICAL ANALYSIS

Statistical analysis was performed using the $\chi^{2}$ test with Yates's correction.

\section{Results}

The occurrence of antiperinuclear factor in the four onset types of patients with JRA, children with SLE, and control subjects is shown in the table. The presence of antiperinuclear factor was increased in undiluted samples of seropositive, polyarticular onset JRA $(83 \%)$. The occurrence in seronegative, polyarticular onset JRA was less (37\%), whereas the occurrence in pauciarticular onset, systemic onset JRA and SLE did not differ from that of the control subjects. The reactivity was unchanged at the 1:5 dilution, but, in most samples, decreased with further dilution of the serum samples. Only two samples showed the 'prozone effect' described by Westgeest et $a^{15}$; these were antiperinuclear factor positive only at higher dilutions (1:10 and above).

The overall sensitivity of the test was $34 \%$ in undiluted serum samples, decreasing to $38 \%$ with the 1:5 dilution. The specificity in the groups that were tested was $90 \%$ (undiluted samples), increasing to $96 \%$ with the $1: 5$ dilution.

\section{Discussion}

This is the first known report of the presence of antiperinuclear factor in a large number of children with JRA or SLE. The overall presence of antiperinuclear factor in patients with JRA (34\%) was lower than reported in adult patients with RA; however, the presence in seropositive patients with polyarticular onset JRA ( $83 \%)$ was comparable. These results are similar to those of Janssens $e t a l^{7}$ who previously found antiperinuclear factor in 3/13 patients with JRA, all of whom were rheumatoid factor positive. Antiperinuclear factor was also noted in $19 \%$ of patients with pauciarticular onset JRA. These patients are being monitored to see if they develop polyarticular disease. If so, the test might have implications for starting treatment with disease modifying drugs earlier. The occurrence of antiperinuclear factor in children with SLE and controls was low and similar to that reported in adults. ${ }^{12} 4-81011$

The presence of antiperinuclear factor principally in patients with polyarticular onset JRA supports the view that there are different aetiologies for the various onset types of JRA. It is also another parameter indicating the similarity between polyarticular onset JRA and adult RA. Regarding its diagnostic value, antiperinuclear factor does not offer an advantage over the hidden rheumatoid factor assay in diagnosing JRA. Hidden rheumatoid factor is positive in $60-70 \%$ of patients with JRA and correlates with disease activity. ${ }^{16}$ However, the test is time consuming and is not available in most laboratories, whereas the antiperinuclear factor test is easier to perform.

Antiperinuclear factor tests can be performed in any laboratory capable of carrying out tests for antinuclear antibodies. It should be noted that the proportion of antigen positive donors in the normal population is high, but only a small percentage of these have enough antigen to allow the easy detection of antiperinuclear factor. ${ }^{17}$ The test is reproducible ${ }^{17}$ and seems to be highly specific for JRA and RA. Although less sensitive in patients with JRA than RA, it can still serologically diagnose a third of polyarticular onset, seronegative patients, in addition to being positive in almost all seropositive patients. Thus, if used in addition to rheumatoid factor testing, it may contribute to the serological diagnosis of patients suspected of having JRA. Further testing comparing groups with other arthritides, such as viral arthritis, are necessary to establish the specificity of this test.

Supported in part by grants from Employees Charity Services of Supported in part by grants from Employees Charity Services of the McDonnell-Douglas Corporation of St Louis, the Eastern
Missouri Chapter of The Arthritis Foundation, and the Eastern Missouri Chapter of the Lupus Foundation of America, Inc.

1 Nienhuis R L F, Mandema E. A new serum factor in patients with rheumatoid arthritis - the antiperinuclear factor. $A n n$ Rheum Dis 1964; 23: 302-5.

2 Marmont A M, Damasio E E, Bertorello C, Rossi F. Studies on the antiperinuclear factor. Arthritis Rheum 1967; 10: on the

3 Vivino F B, Maul G G. Histologic and EM features of the antiperinuclear factor antigen. Arthritis Rheum 1989; 32: S96.

4 Youinou P, Pennec Y, LeGoff P, Ferec C, Morrow W J W, LeMenn G. Antiperinuclear factor in Sjögren's syndrome in the presence or absence of rheumatoid arthritis. Clin Exp Rheumatol 1984; 2: 5-9.

5 Westgeest A A A, Boerbooms A M T, Jongmans $M$, Vandenbroucke J P, Vierwinden G, van de Putte L B A. Antiperinuclear factor: indicator of more severe disease in Antiperinuclear factor: indicator of more severe disease in
seronegative rheumatoid arthritis. $\mathcal{J}$ Rheumatol 1987; 14: 893-7.

6 Kataaha P K, Mortazavi-Milani S M, Russel G, Holborow E J. Anti-intermediate filament antibodies; antikeratin antibody, and antiperinuclear factor in rheumatoid arthritis and infectious mononucleosis. Ann Rheum Dis 1985; 44: 446-9.

7 Janssens X, Veys E M, Verbruggen G, DeClercq L. The 
dragnostic signiticance of the antiperinuclear factor for rheumatoid arthritis. 7 Rheumatol 1988; 15: 1346-50.

8 Westgeest A A A, van Loon A J, van der Logt J T M, van der Putte L B A, Boerbooms A M T. Antiperinuclear factor, a rheumatoid arthritis specific autoantibody: its relation to Epstein-Barr virus. F R heumatol 1989; 16: 626-30.

9 Vivino F B, Maul G. Antiperinuclear factor prevalence in rheumatic diseases. Arthritis Rheum 1989; 32: S95.

10 Johnson G D, Carvalho A, Holborow E J, Goddard D H, Russell G. Antiperinuclear factor and keratin antibodies in rheumatoid arthritis. Ann Rheum Dis 1981; 40: 263-6.

11 Sondag-Tschroots I R J M, Aaij C, Smit J W, Feltkamp T E W. The antiperinuclear factor: 1 . The diagnostic significance of the antiperinuclear factor for rheumatoid arthritis. Ann Rheum Dis 1979; 38: 248-51.

12 Boerboom A M T, Westgeest A A A, Reekers P, van de Putte L B A. Immunogenetic heterogeneity of seronegative rheumatoid arthritis and the antiperinuclear factor. Ann Rheum Dis 1990; 49: 15-7.

13 Cassidy J T, Levinson J E, Bass J, et al. A study of classification criteria for a diagnosis of juvenile rheumatoid arthritis. Arthritis Rheum 1986; 29: 274-81.

14 Tan E M, Cohen A S, Fries J F, et al. The 1982 revised criteria for the classification of systemic lupus erythematosus. Arthritis Rheum 1982; 25: 1271-7.

15 Westgeest A A A, Boerbooms A M T, van de Putte L B A. The influence of serum dilution on findings of antiperinuclear factor prevalence in rheumatoid arthritis. Arthritis Rheum 1990; 33: 759-60.

16 Moore T I Dorner R W, Osborn T G, Zuckner J. Hidden 19S IgM rheumatoid factors. Semin Arthritis Rheum 1988; 19S IgM $72-5$.

17 Veys E M, Keyser F D, Vlam K D, Verbruggen G. The antiperinuclear factor. Clin Exp Rheumatol 1990; 8: 429-31. 